\title{
Determinan Harga Saham pada Perusahaan yang Terdaftar di Jakarta Islamic Index (JII)
}

\author{
Erna Pratika Sari ${ }^{*}$, Anita Wijayanti ${ }^{2}$, Purnama Siddi $^{3}$ \\ ${ }^{1,2,3}$ Universitas Islam Batik Surakarta \\ *correspondence email: ernapratika63@gmail.com
}

\begin{abstract}
Valuation of stock prices is very important to be carried out by shareholders because stocks is promising type of investment. Examining the effect of of PER, GPM, ROE and operating cash flow on stock prices in companies listed on the Jakarta Islamic Index (JII) in 2015-2018 are the objectives of this research. With secondary data used in this research. Population in the study used 16 companies listed on the Jakarta Islamic Index (JII) in 2015-2018. Sampling using a purposive sampling method and samples obtained by 8 companies. Analysis with multiple linear regression. PER and GPM do no affect stock prices, while ROE and operating cash flow affect stock prices are the results of the study.
\end{abstract}

Keyword : AKO; GPM; PER; ROE; Stock Price

\section{PENDAHULUAN}

Pasar modal bisa dijadikan penopang perekonomian suatu negara. Pasar modal memainkan peran penting dalam kemakmuran ekonomi yang mendorong pembentukan modal dan pertumbuhan ekonomi yang berkelanjutan. Dengan hadirnya pasar modal dapat memperluas pilihan investor untuk berinvestasi dan berkesempatan memperoleh return dan mempertimbangkan risk yang ada. Sebagai negara dengan penduduk yang mayoritas penduduknya muslim, Indonesia perlu mengembangkan pasar modal syariah. Hal ini bertujuan supaya masyarakat muslim bisa ikut berinvestasi sesuai dengan prinsip dasar syariah tanpa mempersoalkan halal dan haram. Saham yang tergolong syariah serta yang sering diperdagangkan masuk dalam indeks Jakarta Islamic Index (JII), sehingga JII bisa dijadikan pilihan masyarakat muslim ketika hendak berinvestasi.

Kegiatan menanam modal (berinvestasi) secara aman, nyaman dan sesuai dengan kaidah dasar syariah tak kalah menjanjikan dibanding dengan investasi pada umumnya. Berdasarkan catatan BEI hingga 17 September 2019, JII mampu bertumbuh 18,5\% hasil ini lebih baik daripada IHSG yang tumbuh sejak awal tahun sebesar 0,68\%. Saham perusahaan yang menjadi penggerak seperti ICBP-Indofood CBP Sukses Makmur Tbk (6,4\%), UNVR-Unilever Indonesia Tbk (16,5\%), ASII-Astra International Tbk (12,4\%) dan TLKM-Telekomunikasi Indonesia Persero Tbk $(19,4 \%)$ (Muamar, 2019). Harga saham ditentukan oleh harga dari supply dan demand akan saham itu sendiri. Penilaian harga saham sangat penting dilakukan oleh investor karena investasi yang cukup menguntungkan salah satunya ialah saham. Semakin ramai penanam modal membeli saham mengakibatkan kenaikan harga saham, begitu sebaliknya (Rahmadewi \& Abundanti, 2018).

Harga saham bisa digunakan sebagai tolok ukur kinerja keuangan perusahaan yang baik atau tidak, sehingga bisa dikatakan perusahaan dalam kondisi yang wajar. Kinerja keuangan yang semakin efisien membuat harga saham juga semakin baik (Permadi et al., 2017). Maka dari itu wajar jika perusahaan menjaga harga sahamnya supaya menunjukkan keadaan industri yang sebenarnya. Informasi-informasi terkait laporan keuangan yang relevan dan akurat bisa digunakan investor sebagai alat analisis pengambilan keputusan berinvestasi. Maka penelitian ini menggunakan kinerja keuangan dengan anlisis rasio keuangan yang terdiri dari PER, GPM, ROE dan Arus Kas Operasi (AKO). Berkaitan dengan variabel yang dipakai, masih terdapat hasil yang kontradiktif. Penelitian Desiana (2017), Ghimire \& Mishra (2018), Rahmadewi \& Abundanti (2018) dan Lestari \& Suryantini (2019) menunjukkan harga saham dipengaruhi Price Earning Ratio (PER). Sedangkan Warrad (2017), Astuti et al., (2018) dan Putranto \& Darmawan (2018) menunjukkan harga saham tidak dipengaruhi PER. Penelitian Ferdian et al., (2018) dan Sugiarto et al., (2019) menunjukkan harga saham dipengaruhi Gross Profit Margin (GPM), namun Rizal \& Sahar (2015) dan Ramfineli \& Ibrahim (2016) menyatakan harga saham tidak dipengaruhi GPM. Penelitian Rahmadewi \& Abundanti (2018), Sugiarto et al., (2019), Mu'arifah \& Sam'ani (2019) dan Pratama et al., (2019) menunjukkan harga saham dipengaruhi ROE sedangkan Asnaini et al., (2016) menjelaskan ROE tidak mempengaruhi harga saham. Penelitian Mufidah (2017) dan Santoso \& Manaf (2019) menunjukkan arus kas operasi mempengaruhi harga saham, sedangkan Permadi et al., (2017) menyatakan harga saham tidak dipengaruhi arus kas operasi. Jadi ditemukan perbedaan hasil penelitian pada variabel-variabel berikut PER, GPM, ROE dan arus kas operasi, sehingga inilah yang menjadi gap research dalam riset ini.

Bersumber dari paparan diatas maka dibentuklah rumusan masalah yakni "Apakah ada pengaruh PER, GPM, ROE dan AKO terhadap harga saham pada emiten yang tercatat di JII tahun 2015-2018?. Riset ini dilakukan guna 
menguji pengaruh PER, GPM, ROE dan AKO terhadap harga saham. Manfaat riset ini ialah sebagai bahan rujukan pengembangan ilmu akuntansi khususnya bidang pasar modal mengenai harga saham dan menjadi bahan evaluasi bagi investor ketika akan berinvestasi.

\section{Tinjauan Pustaka}

Teori Signalling

Teori sinyal berisi tentang isyarat yang diberikan manajemen kepada investor mengenai prospek perusahaan yang nantinya bisa digunakan investor sebagai informasi atau petunjuk dalam berinvestasi (Brigham \& Houston, 2011). Kualitas perusahaan yang dinilai efisien akan memberikan isyarat yang bagus pada pasar dan diharapkan penanam modal dapat menyeleksi kualitas emiten mana yang baik dan yang buruk. Untuk itu dibutuhkan informasiinformasi akurat dan relevan oleh investor, informasi ini digunakan sebagai alat analisis dalam pengambilan keputusan berinvestasi. Perusahaan yang menyampaikan laporan keuangan secara transparan bisa menarik investor untuk berinvestasi.

\section{Harga Saham}

Pada mekanisme pasar harga saham bisa ditentukan dari permintaan jual beli saham dan bisa menjadi harga jual antar investor (Zaki et al., 2017). Harga saham merupakan salah satu indikator keberhasilan suatu perusahaan. Tingginya harga saham, menjelaskan bahwa nilai perusahaan juga tinggi karena kinerja perusahaan tersebut efisien. Berlandaskan penjelasan diatas dapat ditarik kesimpulan harga saham ialah nilai yang tercantum di pasar pada suatu masa yang dipengaruhi adanya demand dan supply. Harga saham tinggi menandakan bahwa nilai suatu perusahaan semakin baik pula.

\section{Price Earning Ratio (PER)}

PER dapat dipakai investor sebagai alat untuk memperkirakan nilai saham yang bisa dilihat dari relasi atas harga saham dengan laba per saham (Rahmadewi \& Abundanti, 2018). PER yang tinggi akan memiliki kesempatan dalam tingkat kemajuan perusahaan yang baik pula. Hal ini bisa menjadi isyarat atau berita positif bagi investor ketika akan berinvestasi dan mengakibatkan kenaikan harga saham perusahaan.

\section{Gross Profit Margin (GPM)}

Menurut Munawir (2016) Gross Profit Margin (GPM) merupakan rasio antara gross profit (laba kotor) yang diperoleh perusahaan dengan tingkat penjualan yang dicapai pada tahun yang sama. Gross Profit Margin (GPM) memuat informasi mengenai besarnya laba yang dihasilkan perusahaan semasa kegiatan operasi. GPM yang tinggi mengindikasikan harga saham juga naik. Tingginya GPM memperlihatkan keadaan operasi perusahaan memiliki kapasitas untuk memaksimalkan profit dengan menekan harga pokok penjualan, sehingga penanam modal terbujuk dengan penawaran saham dan dapat menaikkan harga saham (Gustmainar \& Mariani, 2018 ).

\section{Return on Equity (ROE)}

Menurut Kasmir (2010) Return on Equity (ROE) adalah rasio yang digunakan untuk mengukur laba bersih sesudah pajak dengan modal sendiri. Tingginya nilai ROE akan mendorong penanam modal untuk berinvestasi dikarenakan kinerja perusahaan baik sehingga harga saham bergerak naik, dan sebaliknya.

\section{Arus Kas Operasi (AKO)}

Menurut Harahap (2013) arus kas kegiatan operasi merupakan aktivitas penghasil utama pendapatan perusahaan dan aktivitas lain yang bukan termasuk aktivitas investasi dan aktivitas pendanaan. Perusahaan yang menghasilkan kas dalam jumlah yang tinggi, diharapkan mampu membuat investor percaya jika operasi perusahaan mampu memperoleh kas yang memadai untuk membiayai pinjaman, membagikan deviden kepada pemegang saham serta melakukan kegiatan penanaman modal yang baru tanpa menggunakan dana lain (Mufidah , 2017 ). Apabila nilai arus kas operasi tinggi menandakan kegiatan operasional berjalan dengan baik dan mengakibatkan harga saham cenderung bergerak naik karena arus kas yang tinggi dapat digunakan sebagai bahan pertimbangan investor ketika berinvestasi.

\section{Hipotesis}

\section{Pengaruh PER terhadap harga saham}

Penelitian Desiana (2017), Ghimire \& Mishra (2018), Rahmadewi \& Abundanti (2018) dan Lestari \& Suryantini (2019) menunjukkan PER mempengaruhi harga saham. PER yang tinggi menjelaskan perusahaan mempunyai peluang dalam peningkatan harga saham. Sedangkan Warrad (2017), Astuti et al., (2018) dan Putranto \& Darmawan (2018) menyatakan PER tidak mempengaruhi harga saham. Hipotesis dirumuskan sebagai berikut: H1: 
PER berpengaruh pada harga saham

\section{Pengaruh GPM terhadap harga saham}

Penelitian Ferdian et al., (2018) dan Sugiarto et al., (2019) menjelaskan GPM mempengaruhi harga saham. Tingginya GPM dapat mencerminkan bahwa keadaan operasi emiten mempunyai kemampuan memaksimalkan laba dengan efisien, sehingga bisa diindikasikan harga saham akan naik. Namun Rizal \& Sahar (2015) dan Ramfineli \& Ibrahim (2016) menunjukkan GPM tidak mempengaruhi harga saham. Dari paparan diatas hipotesis dirumuskan sebagai berikut : H2: GPM berpengaruh pada harga saham

\section{Pengaruh ROE terhadap harga saham}

ROE dipakai sebagai alat ukur untuk mengetahui sampai mana emiten mengelola sumber dayanya untuk memperoleh profit atas ekuitas yang dimiliki. ROE yang tinggi menjelaskan kinerja perusahaan dikelola secara efektif dan mengakibatkan harga saham cenderung naik. Penelitian Rahmadewi \& Abundanti (2018), Sugiarto et al., (2019), Mu'arifah \& Sam'ani (2019) dan Pratama et al., (2019) menunjukkan ROE mempengaruhi harga saham. Sedangkan Asnaini et al., (2016) menunjukkan ROE tidak mempengaruhi harga saham, sehingga rumusan hipotesis sebagai berikut : H3: ROE berpengaruh pada harga saham

\section{Pengaruh Arus Kas Operasi (AKO) terhadap harga saham}

Arus kas operasi merupakan kegiatan penghasil utama pendapatan emiten. Tingginya arus kas operasi menandakan harga saham juga tinggi. Mufidah (2017) dan Santoso \& Manaf (2019) mengungkapkan AKO mempengaruhi harga saham. Sedangkan Permadi et al., (2017) menyatakan AKO tidak mempengaruhi harga saham. Hipotesis dirumuskan sebagai berikut: H4: AKO berpengaruh pada harga saham

\section{METODE}

Data sekunder dipakai dalam riset ini dan didapat dari annual report emiten yang terdaftar di JII tahun 20152018 didapat melalui website www.idx.co.id. Industri yang tercatat di JII tahun 2015-2018 merupakan populasi yang dipakai dan diperoleh 16 perusahaan. Sampel diperoleh sebanyak 8 perusahaan dengan metode purposive sampling.

Tabel 1

Hasil Pemilahan Sampel

\begin{tabular}{|c|c|c|}
\hline No. & Kriteria & Jumlah \\
\hline 1 & $\begin{array}{l}\text { Emiten yang tercatat berturut- } \\
\text { turut di JII tahun } 2015-2018 \text {. }\end{array}$ & 16 \\
\hline 2 & $\begin{array}{l}\text { Annual reoprt perusahaan yang } \\
\text { tidak memakai rupiah. }\end{array}$ & (3) \\
\hline 3 & $\begin{array}{l}\text { Emiten yang mengalami kerugian } \\
\text { semasa tahun } 2015-2018 \text {. }\end{array}$ & $\mathrm{O}$ \\
\hline 4 & $\begin{array}{l}\text { Data yang disajikan tidak lengkap } \\
\text { terkait informasi yang dipakai } \\
\text { dalam riset. }\end{array}$ & (5) \\
\hline \multicolumn{2}{|c|}{ Jumlah sampel perusahaan } & 8 \\
\hline \multicolumn{2}{|r|}{ Jumlah sampel penelitian (4 x 8) } & 32 \\
\hline
\end{tabular}

Analisis data dengan regresi linier berganda, persamaannya

\section{$: Y=a+b 1 P E R+b 2 G P M+b 3 R O E+b 4 A K O+\varepsilon$}

Keterangan: $\mathrm{Y}=$ harga saham; $\alpha=$ konstanta; $\mathrm{b}_{1}, \mathrm{~b}_{2}, \mathrm{~b}_{3}, \mathrm{~b}_{4}=$ koefisien regresi; PER = Price Earning Ratio; GPM = Gross Profit Margin; $\mathrm{ROE}=$ Return On Equity; $\mathrm{AKO}=$ Arus Kas Operasi; $\varepsilon=$ eror

\section{HASIL}

Tabel 2 diperoleh data sebanyak 32. Nilai terendah harga saham diperoleh 1320, sedangkan tertinggi diperoleh 55900. Nilai mean diperoleh sebesar 13697,6 dan nilai standar deviasi sebesar 14111,84963. PER memiliki nilai terkecil 5,71 dan nilai terbesar diperoleh 60,89. Mean diperoleh sebesar 23,2239 dan standar deviasinya 12,63235. Rata-rata nilai GPM diperoleh 0,3130 dan standar deviasi 0,12346. GPM terkecil diperoleh 0,14, sedangkan nilai terbesar 0,52. Standar deviasi ROE diperoleh 0,38585 dan rata-rata 0,2843. Nilai terkecil ROE sebesar 0,05 sedangkan nilai terbesar diperoleh 1,36. Nilai terendah AKO diperoleh 5,33, sedangkan nilai tertinggi sebesar 5082,86. Nilai mean AKO sebesar 900,706 dan standar deviasi sebesar 1114,46471. 
Tabel 2

Hasil Statistik Deskriptif

\begin{tabular}{lcrrrr}
\hline Variabel & N & Minimum & Maksimum & Mean & $\begin{array}{c}\text { Standar } \\
\text { Deviasi }\end{array}$ \\
\hline HS & 32 & 1320 & 55900 & 13698 & 14111,84963 \\
PER & 32 & 5,71 & 60,89 & 23,224 & 12,63235 \\
GPM & 32 & 0,14 & 0,52 & 0,313 & 0,12346 \\
ROE & 32 & 0,05 & 1,36 & 0,2843 & 0,38585 \\
AKO & 32 & 5,33 & 5082,86 & 900,71 & 1114,46471 \\
\hline \multicolumn{4}{l}{ Sumber $:$ Hasil Olah Data 2020}
\end{tabular}

Tabel 3

Hasil Uji Normalitas

\begin{tabular}{lccc}
\hline & Sig. & Standar & Keterangan \\
\hline Ustandardized Residual & 0,200 & $>0,05$ & Terdistribusi Normal \\
\hline Sumber : Hasil Olah Data 2020 & &
\end{tabular}

Tabel 3 data berdistribusi normal, bisa dilihat dari signifikansi 0,200 >0,05.

Tabel 4

Hasil Uji Multikolinearitas

\begin{tabular}{|c|c|c|c|c|c|}
\hline Variabel & Tolerance & Standar & VIF & Standar & Keterangan \\
\hline PER & 0.270 & $>0,10$ & 3,709 & $<10$ & $\begin{array}{l}\text { Tidak Terjadi } \\
\text { Multikolinearitas }\end{array}$ \\
\hline GPM & 0,434 & $>0,10$ & 2,303 & $<10$ & $\begin{array}{l}\text { Tidak Terjadi } \\
\text { Multikolinearitas }\end{array}$ \\
\hline ROE & 0,353 & $>0,10$ & 2,83 & $<10$ & $\begin{array}{l}\text { Tidak Terjadi } \\
\text { Multikolinearitas }\end{array}$ \\
\hline $\mathrm{AKO}$ & 0,899 & $>0,10$ & 1.113 & $<10$ & $\begin{array}{c}\text { Tidak Terjadi } \\
\text { Multikolinearitas }\end{array}$ \\
\hline
\end{tabular}

Sumber : Hasil Olah Data 2020

Tabel 4 memperlihatkan tolerance $>0,10$ dan $\mathrm{VIF}<10$, sehingga data bebas dari multikolinearitas.

Tabel 5

Hasil Uji Autokorelasi

\begin{tabular}{ccccc}
\hline DW & DU & 4-DU & Std. & Keterangan \\
\hline 1,833 & 1,7323 & 2,2677 & $\mathrm{DU}<\mathrm{DW}<$ 4-DU Bebas Autokorelasi \\
\hline \multicolumn{5}{l}{ Sumber : Hasil Olah Data 2020}
\end{tabular}

Tabel 5 memperlihatkan nilai DU<DW<4-DU $(1,7323<1,833<2,2677)$ sehingga diketahui data penelitian ini bebas autokorelasi.

Tabel 6

Hasil Uji Heteroskedastisitas

\begin{tabular}{lccc}
\hline Variabel & $\begin{array}{c}\text { Ustandardized } \\
\text { Residual }\end{array}$ & Standar & Keterangan \\
\hline PER & 0,651 & $>0,05$ & Bebas Heteroskedastisitas \\
GPM & 0,579 & $>0,05$ & Bebas Heteroskedastisitas \\
ROE & 0,340 & $>0,05$ & Bebas Heteroskedastisitas \\
AKO & 0,061 & $>0,05$ & Bebas Heteroskedastisitas \\
\hline
\end{tabular}

Sumber : Hasil Olah Data 2020

Tabel 6 menerangkan bahwa nilai Unstandardized Residual untuk semua variabel independen > 0,05, maka diketahui bebas dari heteroskedastisitas. 
Tabel 7

Hasil Uji Model Regresi

\begin{tabular}{lr}
\hline Variabel & Unstandardized B \\
\hline Konstanta & 561,960 \\
PER & 230,122 \\
GPM & $-18066,517$ \\
ROE & 28213,074 \\
AKO & 6,025 \\
\hline Sumber Hasil Olah Data 2020 & \\
\hline
\end{tabular}

Persamaan model regresi dari Tabel 7 dinyatakan sebagai berikut : Harga saham $=561,960+230,122$ PER 18066,517 GPM + 28213,074 ROE + 6,025 AKO

Uji Kelayakan Model

Tabel 8

Hasil Uji Kelayakan Model

\begin{tabular}{cccccc}
\hline $\mathbf{F}_{\text {hitung }}$ & $\mathbf{F}_{\text {tabel }}$ & Std & Sig. & Std. & Keterangan \\
\hline 80,710 & 2,728 & $F_{\text {hitung }}>F_{\text {tabel }}$ & 0,000 & $<0,05$ & Model Layak \\
\hline
\end{tabular}

Sumber : Hasil Olah Data 2020

Tabel 8 menunjukkan bahwa model layak, dikarenakan $\mathrm{F}_{\text {hitung }}>\mathrm{F}_{\text {tabel }}(80,710>2,728)$ dan signifikansi<0,05 $(0,000<0,05)$. Dengan demikian secara bersama-sama harga saham dipengaruhi PER, GPM, ROE dan AKO.

Uji Hipotesis

Tabel 9

Hasil Uji Hipotesis

\begin{tabular}{llcccc}
\hline Hipotesis & $\mathbf{t}_{\text {hitung }}$ & $\mathbf{t}_{\text {tabel }}$ & Sig. & Standar & Keterangan \\
\hline $\mathrm{H}_{1}$ (PER) & 2,001 & 2,05183 & 0,056 & $<0,05$ & Ditolak \\
$\mathrm{H}_{2}(\mathrm{GPM})$ & $-1,948$ & $-2,0518$ & 0,062 & $<0,05$ & Ditolak \\
$\mathrm{H}_{3}$ (ROE) & 8,577 & 2,05183 & 0,000 & $<0,05$ & Diterima \\
$\mathrm{H}_{4}$ (AKO) & 8,436 & 2,05183 & 0,000 & $<0,05$ & Diterima \\
\hline
\end{tabular}

Sumber : Hasil Olah Data 2020

Tabel 9 menunjukkan 2 variabel yang berpengaruh yaitu: ROE dan AKO dengan signifikansi $0,000<0,05$, jadi diketahui ROE dan AKO mempengaruhi harga saham, namun PER $(0.056>0,05)$ dan GPM $(0,062>0,05)$, sehingga PER dan GPM tidak berpengaruh.

Uji Koefisien Determinasi

Tabel 10

Hasil Uji Koefisien Determinasi

\begin{tabular}{llll}
\hline & Model & Adjsd. $\mathbf{R}^{\mathbf{2}}$ & Keterangan \\
\hline 1 & & 0,911 & Berpengaruh $91,1 \%$ \\
\hline
\end{tabular}

Sumber : Hasil Olah Data 2020

Tabel 10 memperlihatkan bahwa PER, GPM, ROE dan AKO mampu menjelaskan harga saham sebesar $91,1 \%$, sedangkan sebab di luar regresi diterangkan sebesar $8,9 \%$.

Hipotesis 1 ditolak. Variabel PER tidak mempengaruhi harga saham. Hasil penelitian ni menunjukkan bahwa nilai Price Earning Ratio (PER) tidak berpengaruh terhadap harga saham. Price Earning Ratio (PER) tidak berpengaruh terhadap harga saham bisa disebabkan karena perusahaan kurang efektif dalam menghasilkan laba. Sehingga Price Earning Ratio (PER) yang tinggi maupun yang rendah tidak mempengaruhi harga saham. Hasil pengujian konsisten dengan Warrad (2017), Astuti et al ., (2018) dan Putranto \& Darmawan (2018) yang menunjukkan harga saham tidak dipengaruhi PER. Namun hasil ini tidak sejalan dengan Desiana (2017), Ghimire \& Mishra (2018), Rahmadewi \& Abundanti (2018) dan Lestari \& Suryantini (2019) yang menunjukkan harga saham dipengaruhi PER. Hipotesis 2 ditolak. Variabel Gross Profit Margin (GPM) tidak mempengaruhi harga saham. Riset ini konsisten dengan Rizal \& Sahar (2015) dan Ramfineli \& Ibrahim (2016) yang menunjukkan Gross Profit Margin 
(GPM) tidak mempengaruhi harga saham. Riset ini berbanding terbalik Ferdian et al., (2018) dan Sugiarto et al., (2019) mengungkapkan harga saham dipengaruhi GPM. Penelitian ini menunjukkan bahwa Gross Profit Margin (GPM) tidak berpengaruh terhadap harga saham. Hal ini dikarenakan perusahaan kurang optimal dalam memaksimalkan penjualan dalam menghasilkan laba kotor. Sehingga, tinggi rendahnya tingkat Gross Profit Margin (GPM) suatu perusahaan tidak mempengaruhi harga saham. Hipotesis 3 diterima. Variabel ROE mempengaruhi harga saham. Riset ini mendukung Rahmadewi \& Abundanti (2018), Sugiarto et al., (2019), Mu'arifah \& Sam'ani (2019) dan Pratama et al., (2019) yang menunjukkan ROE mempengaruhi harga saham. Riset ini berbanding terbalik Asnaini et al., (2016) yang mengungkapkan ROE tidak mempengaruhi harga saham. ROE memperlihatkan kapasitas perusahaan dalam memperoleh profit atas penanaman modal yang dilakukan oleh investor. ROE yang tinggi menunjukkan profit yang diperoleh perusahaan juga maksimal karena industri mampu mengelola modal seefisien mungkin. Kondisi ini berdampak pada permintaan pasar yang semakin banyak dan secara langsung mengakibatkan harga saham bergerak naik. Hipotesis 4 diterima. Variabel arus kas operasi (AKO) mempengaruhi harga saham. Riset ini mendukung Mufidah (2017) dan Santoso \& Manaf (2019) menunjukkan harga saham dipengaruhi AKO. Sedangkan hasil ini kontradiktif oleh Permadi et al., (2017) yang menunjukkan AKO tidak mempengaruhi harga saham. Arus kas operasi bisa dijadikan sebagai indikator dalam penentuan operasi perusahaan ketika memperoleh arus kas. Dana yang dipakai untuk membiayai pinjaman, membagikan deviden serta melakukan kegiatan penanaman modal baru lainnya berasal dari arus kas operasi. Tingginya arus kas operasi menunjukkan industri mampu membagikan deviden dangan lancar, hal ini bisa dijadikan patokan investor ketika akan berinvestasi. Arus kas operasi perusahaan yang tinggi akan memicu penanam modal berinvestasi, secara otomatis akan meningkatkan harga saham.

\section{SIMPULAN}

Riset ini dilakukan guna menguji pengaruh PER, GPM, ROE dan AKO terhadap harga saham. Diperoleh 32 data observasi dengan analisis regresi linier berganda. Uji t memperlihatkan PER dan GPM tidak mempengaruhi harga saham, namun ROE dan AKO mempengaruhi harga saham. Nilai Adjusted $\mathrm{R}^{2}$ sebesar $91,1 \%$ artinya, PER, GPM, ROE dan AKO mampu menjelaskan harga saham sebesar 91,1\%, sedangkan 8,9\% sisanya diterangkan oleh faktor lain diluar regresi.

\section{DAFTAR PUSTAKA}

Asnaini, Elvira, R., \& Yuningsih, A. 2016. Pengaruh Profitabilitas Dan Nilai Pasar Terhadap Harga Saham Syariah Pada Perusahaan Yang Terdaftar Di Jakarta Islamic Index (JII) Tahun 2011-2013. Baabu Al-Ilmi Vol. 1 No.2, 144-164.

BIBLIOGRAPHY \I 1057 Astuti, P., Sari , Y. L., \& WA , A. R. (2018). Analisis Pengaruh Return On Equity, Earning Per Share, Price To Book Value, Book Value Per Share, Price Earning Ratio dan Kepemilikan Institusional terhadap Harga Saham. Jurnal Ekonomi, Volume 20 Nomor 2, 170-183.

BIBLIOGRAPHY ll 1057 Brigham, E. F., \& Houston, J. F. (2011). Dasar-Dasar Manajemen Keuangan Terjemahaan. Jakarta: Salemba Empat.

Chandrarin, G. 2018. Metode Riset Akuntansi Pendekatan Kuantitatif. Jakarta: Salemba Empat.

Desiana, L. 2017. Pengaruh Price Earning Ratio (PER), Earning Per Share (EPS), Devidend Yield Ratio (DYR), Dividend Payout Ratio (DPR), Book Value Per Share (BVS) Dan Price Book Value (PBV) Terhadap Harga Saham Pada Perusahaan Subsektor Makanan Dan Minuman Yang Terdaftar D. I-Finance Vol. 3. No. 2, 199212.

Ferdian, R., Suryadi, E., \& Safitri , H. 2018. Analisis Dividend Payout Ratio (DPR), Gross Profit Margin (GPM), dan Net Profit Margin (NPM) Terhadap Harga Saham Indeks PEFINDO-25. Jurnal Produktivitas 5 , 43-48.

Ghimire, R. R., \& Mishra, D. 2018. Determinants of Stock Price in Nepalese Market. The International Research Journal of Management Sceince Vol.3 No.1, 124-135.

Gustmainar, J., \& Mariani. 2018. Analysis Of The Effect Of Current Ratio, Debt To Equity Ratio, Gross Profit Margin, Return On Investment, And Earning Per Share On Stock Prices At LQ 45 Companies Listed On The Indonesia Stock Exchange In The Year Of 2010-2016. BILANCIA Vol. 2 No. 4, 465-476.

Harahap, S. S. (2013). Teori Akuntansi Edisi Revisi 2011. Jakarta: Rajawali Pers.

Kasmir. (2010). Pengantar Manajemen Keuangan. Jakata: Kencana.

Muamar, Y. 2019, September 18. Cuan! Kinerja Islamic Index Lebih Unggul Dibandingkan IHSG. Dipetik Desember 17, 2019, dari CNBC Indonesia: https://www.cnbcindonesia.com/syariah/20190918133047-29-100350/cuankinerja-islamic-index-lebih-unggul-dibandingkan-ihsg

Mufidah, E. 2017. Analisis Laba, Arus Kas Operasi Dan Nilai Buku Ekuitas Terhadap Harga Saham. EKSIS, Vol 12, No 1, 47-62.

Munawir. (2016). Analisis Laporan Keuangan Edisi Keempat. Yogyakarta: Liberty Yogyakarta. 
Permadi, T. D., Widarnoi, B., \& Astuti, D. S. 2017. Pengaruh Komponen Arus Kas Terhadap Harga Saham Pada Perusahaan BUMN Yang Terdaftar Di Bursa Efek Indonesia. Jurnal Akuntansi dan Sistem Teknologi Informasi Vol. 13 No 3, $331-341$.

Pratama , C. A., Azizah , D. F., \& Nurlaily , F. 2019. Pengaruh Return On Equity (ROE), Earning Per Share (EPS), Current Ratio (CR) Dan Debt To Equity Ratio (DER) Terhadap Harga Saham (Studi pada Perusahaan Jakarta Islamic Index yang Terdaftar di Bursa Efek Indonesia Tahun 2014-2017). Jurnal Administrasi Bisnis (JAB)|Vol. 66 No. $1,10-17$.

Putranto , A. D., \& Darmawan, A. 2018. Pengaruh Ukuran Perusahaan, Profitabilitas, Leverage, Dan Nilai Pasar Terhadap Harga Saham (Studi Kasus Pada Perusahaan Pertambangan Yang Terdaftar Di Bursa Efek Indonesia Periode 2010-2016). Jurnal Administrasi Bisnis (JAB)|Vol. 56 No. 1 , 110-117.

Rahmadewi, P. W., \& Abundanti, N. 2018. Pengaruh EPS, PER, CR, Dan ROE Terhadap Harga Saham Di Bursa Efek Indonesia. E-Jurnal Manajemen Unud, Vol. 7, No. 4, 2106-2133.

Ramfineli, R. H., \& Ibrahim, M. 2016. Analisis Kinerja Keuangan Dengan Rasio Profitabilitas Dan Pengaruhnya Terhadap Harga Saham Perusahaan Sektor Industri Dasar Dan Kimia Sub Sektro Pulp \& Paper Di Bursa Efek Indonesia. Jom FISIP Volume 3 No. 2, 1-15.

Rizal, \& Sahar, S. (2015). Pengaruh Rasio Keuangan Terhadap Harga Saham Sektor Properti dan Real Estate pada Bursa Efek Indonesia . Kalbisocio, Volume 2 No.1 , 41-51.

Santoso, N., \& Manaf, S. 2019. Analisis Pengaruh Arus Kas Operasional Dan Laba Bersih Terhadap Harga Saham Pada Perusahaan Otomotif Yang Terdaftar Di Bursa Efek Indonesia Tahun 2013-2017. Jurnal Ekonomi Manajemen dan Akuntansi No. 46 / Th. XXVI, 133-150.

Sugiarto, E., Pradana, M. G., \& Muhtarom, A. 2019. Analisis Pengaruh Profitabilitas Terhadap Harga Saham Pada Perusahaan Manufaktur Di Bursa Efek Indonesia (Studi Pada Perusahaan Astra Otoparts, Astra International, Dan Bata Tahun 2013-2017). Media Mahardhika Vol. 17 No. 2, 254-263.

Warrad , L. H. 2017. The Effect of Market Valuation Measures on Stock Price: An Empirical Investigation on Jordanian Banks . International Journal of Business and Social Science, 67-74.

Zaki , M., Islahuddin, \& Shabri, M. 2017. Pengaruh Profitabilitas, Leverage Keuangan Dan Ukuran Perusahaan Terhadap Harga Saham (Studi Pada Perusahaan Manufaktur Yang Terdaftar Di Bursa Efek Indonesia Periode 2005-2014). Jurnal Megister Akuntansi Pascasarjana Universitas Syiah Kuala, 58-66. 